\title{
FT-Raman study of the (sub)picosecond dynamics in genomic DNA from plant tissues
}

\author{
Cristina M. Muntean* and Ioan Bratu \\ National Institute for Research and Development of Isotopic and Molecular Technologies, \\ Cluj-Napoca, Romania
}

\begin{abstract}
In this paper the Raman total half bandwidths of eight genomic DNAs from leaf tissues [potato (Solanum tuberosum L.), sword fern (Nephrolepis exaltata L.), scopolia (Scopolia carniolica Jacq.), redwood (Sequoia sempervirens D. Don. Endl.), orchids (Cymbidium $\times$ hybrida), chrysanthemum (Dendranthema grandiflora Ramat.) and common sundew (Drosera rotundifolia $\mathrm{L}$.)] have been measured. The dependencies of the total half bandwidths and of the global relaxation times, on DNA molecular subgroup structure and on the type of genomic plant DNA, are reported. It is shown that changes in the (sub)picosecond dynamics of molecular subgroups in genomic DNAs from leaf tissues can be monitored with Raman spectroscopy.

Particularly, the Raman band parameters for the vibrations at $879 \mathrm{~cm}^{-1}$ (deoxyribose, dA), $1047 \mathrm{~cm}^{-1}$ (CO stretching C-O$\mathrm{P}-\mathrm{O}-\mathrm{C}, \mathrm{dG}), 1089 \mathrm{~cm}^{-1}$ (P-O symmetric stretching of $\left.\mathrm{PO}_{2}{ }^{-}\right), 1124 \mathrm{~cm}^{-1}(\mathrm{dA}), 1272 \mathrm{~cm}^{-1}(\mathrm{dC}, \mathrm{dG}, \mathrm{dT}), 1276 \mathrm{~cm}^{-1}(\mathrm{dC})$, $1455 \mathrm{~cm}^{-1}$ (deoxyribose, $\mathrm{dA}, \mathrm{dC}, \mathrm{dT}$ ) and $1482 \mathrm{~cm}^{-1}(\mathrm{dG}, \mathrm{dA}$ ) of genomic leaf tissues DNAs are presented. In our study, the full widths at half-maximum (FWHM) of the bands in genomic DNAs from leaf tissues are typically in the wavenumber range from 7.8 to $23.1 \mathrm{~cm}^{-1}$. It can be observed that the molecular relaxation processes studied in this work, have a global relaxation time smaller than $1.36 \mathrm{ps}$ and larger than $0.46 \mathrm{ps}$.

The fastest and the slowest relaxation processes of different DNA structural subgroups, for several types of genomic DNA extracted from leaf tissue, have been analyzed. Particularly, the slowest dynamics corresponding to the vibration near $1272 \mathrm{~cm}^{-1}$ takes place in the case of DNA extracted from common sundew (global relaxation time $1.36 \mathrm{ps}$ ).

A comparison between different time scales of the vibrational energy transfer processes, characterizing several DNA complexes, has been given.

We have found that the bands at $879 \mathrm{~cm}^{-1}$ (deoxyribose, phosphodiester, dA) and $1455 \mathrm{~cm}^{-1}$ (deoxyribose, dA, dC, dT) are suitable for the study of dynamical behavior of molecular subgroups in genomic DNA extracted from leaf tissues.

Specific molecular relaxation processes, depending on the type of genomic DNA extracted from leaf tissues has been observed.

Keywords: (Sub)picosecond dynamics, genomic DNA, leaf tissue, FT-Raman spectroscopy
\end{abstract}

\section{Introduction}

Conformational fluctuations are an important property of biopolymers, and it seems likely that evolution has optimized not only their structure, but also their dynamics. It is well known that the dynamics of biopolymers occurs on a wide range of time scales, extending from seconds to femtoseconds [16].

\footnotetext{
${ }^{*}$ Corresponding author: Dr. Cristina M. Muntean, National Institute for Research and Development of Isotopic and Molecular Technologies, P.O. 5, Box 700, R-400293 Cluj-Napoca, Romania. E-mail: cmuntean@itim-cj.ro.
} 
Particularly, vibrational relaxation plays a crucial role in many aspects of chemistry, physics and biology, e.g. photochemistry, electron transfer, reaction dynamics, thermal chemistry, photobiological processes such as vision and photosynthesis and excimer formation ([1,8] and references therein).

Among the techniques available for the study of molecular motions in liquids, Raman scattering has the distinct advantage, that it enables simultaneous analyses of both reorientational and vibrational processes $([3,4,7]$ and references therein). Studies of molecular relaxations in liquids are valuable in providing information about the intermolecular interaction processes in condensed matter [4].

Vibrational frequencies depend on static molecular parameters as force constants, bond distances and angles, atomic masses and electric charges. Besides, time-dependent forces broaden the vibrational bands [15].

Vibrational energy exchange, vibrational resonance coupling, vibrational dephasing and rotational broadening are a number of dynamical processes which have been considered to broaden the vibrational bands of nucleic acids in the frequency domain $([6,15]$ and references therein). Different relaxation mechanisms may characterize different vibrations, and this kind of information is available from spontaneous Raman measurements ([6-8,15] and references therein).

The macromolecular motion in fluids is generally too slow to be observed in the Raman time window that is accessible in the frequency domain. On contrary, the motion of molecular subgroups can be fast enough [12].

It was demonstrated that Raman bandwidths in polynucleotides range from 8 to 35 wavenumbers, and the corresponding time scale of the perturbing forces ranges from fractions of a picosecond to several picoseconds $[7,15]$.

Upon changing the structure of the nucleic acid by the presence of proteins, ionic salts, $\mathrm{pH}$, metal ions and intercalators, different vibrational modes of the molecule can behave quite different $[5,6,11]$.

A confocal Raman microspectroscopic study into the vibrational half bandwidths of molecular subgroups in calf-thymus DNA, upon lowering the $\mathrm{pH}$, and in the presence of $\mathrm{Na}^{+}, \mathrm{Ca}^{2+}$ and $\mathrm{Mg}^{2+}$ ions, respectively, was previously reported by us [5]. In this study the half bandwidths of the vibrations in calf-thymus DNA were typically in the wavenumber range from 7.4 to $31 \mathrm{~cm}^{-1}$. The bandwidths in the Raman spectra were sensitive to a dynamics active on a time scale from 0.34 to 1.44 ps [5,7].

Also, the dependencies of the full widths at half-maximum (FWHM) and of the global relaxation times on DNA molecular subgroup structure, and on $\mathrm{Mn}^{2+}$ and $\mathrm{Na}^{+}$ions concentrations, respectively, have been reported [6].

The complex system of calf thymus DNA, in an aqueous buffer solution, was studied by Raman spectroscopy, at reduced and low $\mathrm{pH}$ values, in the presence of $\mathrm{Mn}^{2+}$ ions, respectively. The molecular relaxation processes of DNA subgroups were presented. The full widths at half-maximum (FWHM) of the bands in calf-thymus DNA were typically in the wavenumber range from 11 to $27 \mathrm{~cm}^{-1}$ and the molecular relaxation processes studied in that work, had a global relaxation time smaller than $0.965 \mathrm{ps}$ and larger than 0.393 ps [7].

Also the complex system of calf thymus DNA, in an aqueous buffer solution, was studied by Raman spectroscopy, as a function of $\mathrm{Zn}^{2+}$ ions concentration [8]. The molecular dynamics of DNA subgroups was presented. Monitoring the changes in the Raman vibrational full widths at half-maximum (FWHM) and, correspondingly, in the global relaxation times of the molecular subgroups in DNA, upon varying the $\mathrm{Zn}^{2+}$ concentration and in the presence of a constant concentration of $\mathrm{Na}^{+}$ions, was of interest. In this study, the full widths at half-maximum (FWHM) of the bands in calf-thymus DNA complexes were typically in the wavenumber range from 10 to $50 \mathrm{~cm}^{-1}$. It could be observed that the molecular 
relaxation processes studied in this work, had a global relaxation time smaller than 0.94 ps and larger than 0.21 ps [8].

In the study of nucleic acids, phosphate groups are particularly very important in the structure, dynamics and interactions of mono- and polynucleotides [2,6,14]. A study of the dynamics of the $\mathrm{PO}_{3}{ }^{2-}$ group in aqueous solution can give information on the mononucleotide mobility and interactions in its natural solvent $[2,7]$.

FTIR measurements on the $\nu_{s}\left(\mathrm{PO}_{3}{ }^{2-}\right)$ band shape of $5^{\prime}$-CMP in ${ }^{2} \mathrm{H}_{2} \mathrm{O}$ solution at different concentrations, $0.002-0.58 \mathrm{~mol} \mathrm{dm}^{-3}$, and temperatures, $10-55^{\circ} \mathrm{C}$ have been interpreted in terms of the dynamics of the $\mathrm{PO}_{3}{ }^{2-}$ group and the self-association processes of this mononucleotide $[8,10]$.

In relation to the relaxation processes of the IR $\nu_{s}\left(\mathrm{PO}_{3}{ }^{2-}\right)$ band of disodium deoxycytidine $5^{\prime}$ monophosphate, $5^{\prime}$-dCMP, in ${ }^{2} \mathrm{H}_{2} \mathrm{O}$ and $\mathrm{H}_{2} \mathrm{O}$, a band-shape analysis of this vibrational mode has been performed [1]. The second derivative spectra reveal the presence of $5^{\prime}$-dCMP aggregates when concentration reaches $\sim 0.28 \mathrm{~mol} \mathrm{dm}^{-3}$. A similar self-association process was detected for the mononucleotide $5^{\prime}$-CMP $[1,8]$.

In this paper the Raman total half bandwidths of eight genomic DNAs from leaf tissues [potato (Solanum tuberosum L.), sword fern (Nephrolepis exaltata L.), scopolia (Scopolia carniolica Jacq.), redwood (Sequoia sempervirens D. Don. Endl.), orchids (Cymbidium $\times$ hybrida), chrysanthemum (Dendranthema grandiflora Ramat.) and common sundew (Drosera rotundifolia L.)] have been measured. The dependencies of the total half bandwidths and of the global relaxation times, on DNA molecular subgroup structure and on the type of genomic plant DNA, are reported. It is shown that changes in the (sub)picosecond dynamics of molecular subgroups in genomic DNAs from leaf tissues can be monitored with Raman spectroscopy.

\section{Experimental procedure}

The experimental details of the FT-Raman spectra, obtained for genomic DNA from different plant tissues, were given in [9]. Leaves from in vitro-grown species were the source material for extraction of genomic DNAs. These fully expanded leaves were obtained from plants of: potato (Solanum tuberosum L., Fam. Solanaceae), sword fern (Nephrolepis exaltata L., Fam. Polypodiaceae), scopolia (Scopolia carniolica Jacq., Fam. Solanaceae), redwood (Sequoia sempervirens D. Don. Endl., Fam. Taxodiaceae), orchids (Cymbidium $\times$ hybrida, Fam. Orchidaceae), chrysanthemum (Dendranthema grandiflora Ramat., Fam. Asteraceae) and common sundew (Drosera rotundifolia L., Fam. Droseraceae) [9].

Standard FT-Raman measurements have been carried out at room temperature, at the "Babeş-Bolyai" University, Cluj-Napoca, Romania and are presented elsewhere [9]. The FT-Raman spectra were recorded in a backscattering geometry $\left(180^{\circ}\right)$ with a Bruker FRA 106/S Raman accessory equipped with an InGaAs detector and attached to the conventional Bruker Equinox 55 FT-IR spectrometer. The $1064 \mathrm{~nm} \mathrm{Nd:YAG} \mathrm{laser} \mathrm{was} \mathrm{used} \mathrm{as} \mathrm{excitation} \mathrm{source,} \mathrm{and} \mathrm{the} \mathrm{laser} \mathrm{power} \mathrm{was} \mathrm{set} \mathrm{to} 400 \mathrm{~mW}$. 500 scans were accumulated and averaged for each spectrum. All samples were maintained at room temperature $\left(21^{\circ} \mathrm{C}\right)$. Spectra acquisition was performed using Bruker OPUS version 4.0 spectroscopy software. Measurements on the DNA samples were followed by the background signal measurement at identical experimental settings, in order to determine the spectral contribution from the buffer solution and the quartz recipient, which was then subtracted from each DNA sample spectrum [9].

Full widths at half-maximum (FWHM) of the bands were determined using SpectraCalc software. The FWHM was evaluated from the half maximum Raman bands. 


\section{Results and discussions}

In the study of the molecular relaxation processes, Rakov developed one of the well-known procedures of obtaining the relaxation times and the activation energy [5-8,13].

The total half bandwidth of the depolarized Raman lines contains in this approximation, two contributions [5-7]:

- an intrinsic bandwidth, $\delta_{0}$, considered temperature independent in that time;

- another contribution $\Delta(T)$ which is temperature dependent.

The total half bandwidth can be written as:

$$
\Delta \nu_{1 / 2}=\delta_{0}+\Delta(T)=\delta_{0}+\frac{1}{\pi c \tau_{r}} .
$$

The potential barrier against reorientation can be obtained as:

$$
\tau_{r}=\tau_{0} \exp \left(\frac{U_{\text {or }}}{k T}\right)
$$

where $\tau_{0}$ is the period of the molecule oscillation around the equilibrium position, and $U_{\text {or }}$ is the energy barrier or the activation energy $[5,6,8]$.

The Rakov relationship can be written as:

$$
\Delta \nu_{1 / 2}=\delta_{0}+\frac{1}{\pi c \tau_{0}} \exp \left(\frac{-U_{\text {or }}}{k T}\right)
$$

From the $\left(\Delta \nu_{1 / 2}-\delta_{0}\right)$ vs. $\frac{10^{3}}{T}$ dependencies one can obtain $U_{\text {or }}$ as the slope of this linear dependence [5-7].

The temperature "independent" part, due to the vibrational relaxation, $\delta_{v}$, presents small temperature dependence, opposite to the one due to the reorientational relaxation.

The vibrational contribution becomes important for large molecules, in aqueous solutions. From Raman measurements, using polarized light, it is possible to do the selection of these two contributions $[5,6,8]$. One can assume, as a first approximation, the existence of a global relaxation time, $\tau$, obtained from the total Raman half bandwidth. This band parameter can be related with the intrinsic parameters of the analyzed system through the relationship:

$$
\tau_{v, 1 R, 2 R}=\frac{1}{\pi c \Delta \nu_{1 / 2}^{v, 1 R, 2 R}},
$$

where the half bandwidth includes the vibrational $\left(\Delta \nu_{1 / 2}^{v}\right)$ and rotational $\left(\Delta \nu_{1 / 2}^{1 R, 2 R}\right)$ contributions and $c$ is the velocity of light. $\Delta \nu_{1 / 2}^{1 R, 2 R}$ is obtained from IR and Raman bands, respectively [5-7].

One can control the dominant contribution of one or another molecular relaxation process through [5-8]:

(a) the selection of the molecular system;

(b) temperature dependence;

(c) a proper selection of the solvents. 
For mononucleotides [10] or deoxymononucleotides [2] in aqueous solutions, molecular dynamics studies were done by using these approximations $[5,6]$.

The development of fast and accurate curve fitting programs allows the analysis of the vibrational spectra of complicated biological molecules containing often more than 40 vibrational bands ([15] and references therein).

In this paper we will concentrate on the vibrational bandwidths. Only the relatively isolated nucleic acids vibrations will be considered [5,6]. A study into the Raman vibrational bandwidths and the corresponding global relaxation times of molecular subgroups in genomic DNA from different leaf tissues, is of interest.

For the case of aqueous solutions of DNA molecules we can suppose that the dominant relaxation mechanism is the vibrational one. The values of the global relaxation time suggest also the existence of a vibrational relaxation time, because the reorientational movement is much more slower for the DNA macromolecule in aqueous solution [6]. Particularly, the absence of reorientational broadening in polynucleotides indicates that the bases in polynucleotides reorient through an angle of $41^{\circ}$ in times slower than $21 \mathrm{ps}([7,15]$ and references therein).

The Raman band parameters obtained for the vibrations near $879 \mathrm{~cm}^{-1}$ (deoxyribose, phosphodiester, dA), $1047 \mathrm{~cm}^{-1}$ (CO stretching C-O-P-O-C, dG), $1089 \mathrm{~cm}^{-1}$ (P-O symmetric stretching of $\mathrm{PO}_{2}{ }^{-}$), $1124 \mathrm{~cm}^{-1}(\mathrm{dA}), 1272 \mathrm{~cm}^{-1}(\mathrm{dC}, \mathrm{dG}, \mathrm{dT}), 1276 \mathrm{~cm}^{-1}(\mathrm{dC}), 1455 \mathrm{~cm}^{-1}$ (deoxyribose, dA, dC, dT) and $1482 \mathrm{~cm}^{-1}(\mathrm{dG}, \mathrm{dA})$, characteristic to genomic DNAs from different leaf tissues are summarized in Tables 1 and 2, respectively ([9] and references therein).

The full widths at half-maximum (FWHM) of the Raman bands in genomic DNAs from different leaf tissues, are presented for 8 samples, and are typically in the wavenumber range from 7.8 to $23.1 \mathrm{~cm}^{-1}$ (see Table 1). For some wavenumbers the FWHM were not possible to be read. Besides, the global relaxation times were evaluated on the basis of Eq. (4). From the vibrations around 879, 1047, 1089, $1124,1272,1276,1455$ and $1482 \mathrm{~cm}^{-1}$ it can be observed that the global relaxation times, for molecular subgroups in genomic DNA from different leaf tissues, are slower than 0.46 ps and faster than $1.36 \mathrm{ps}$ (see Table 2). The limit values are characterizing the common sundew DNA Raman bands at $1272 \mathrm{~cm}^{-1}$ (global relaxation time $1.36 \mathrm{ps}$ ) and at $1452 \mathrm{~cm}^{-1}$ (global relaxation time $0.46 \mathrm{ps}$ ) and the orchids DNA vibration near $1452 \mathrm{~cm}^{-1}$, respectively (global relaxation time $0.46 \mathrm{ps}$ ). As a general rule, the bandwidths in the Raman spectra are sensitive to a dynamics active on a time scale from 0.1 to $10 \mathrm{ps}$ $[6,15]$.

For the cases of overlapped Raman profiles, only the half of the total half bandwidth (FWHM), in the side where the bands were not superposed, was taken into account and then it was multiplied by two.

The global relaxation time of the band near $879 \mathrm{~cm}^{-1}$ (deoxyribose, phosphodiester, dA) has a range of $0.59-0.80$ ps. Identical values of the Raman total half bandwidths and consequently, of the global relaxation times have been obtained for genomic DNAs isolated from potato, scopolia and redwood leaf tissues, respectively ( $0.69 \mathrm{ps})$. The fastest dynamics of this band was detected for chrysanthemum 1 (global relaxation time $0.59 \mathrm{ps}$ ) and the slowest dynamics was observed for sword fern (global relaxation time $0.80 \mathrm{ps}$ ). In our study, the band near $879 \mathrm{~cm}^{-1}$ is one of the most stable with respect to the type of genomic DNA extracted from leaf tissue, as far as molecular dynamics is concerned.

Referring to the $\mathrm{CO}$ stretching $(\mathrm{C}-\mathrm{O}-\mathrm{P}-\mathrm{O}-\mathrm{C})$ and $\mathrm{dG}$ residues vibration at $1047 \mathrm{~cm}^{-1}$ the vibrational energy transfer processes are almost the same for sword fern, chrysanthemum 1 and chrysanthemum 2 DNAs. The smallest global relaxation time was found for redwood $(0.79 \mathrm{ps})$.

The global relaxation time of the band at $1089 \mathrm{~cm}^{-1}\left(\mathrm{P}-\mathrm{O}\right.$ sym. stretching of $\mathrm{PO}_{2}{ }^{-}$) varied between 0.55 and $0.80 \mathrm{ps}$, being identically for genomic DNAs isolated from sword fern, redwood and chrysan- 
Table 1

Raman total half bandwidths $\left(\mathrm{cm}^{-1}\right)$ of vibrations in genomic DNA from different leaf tissues

\begin{tabular}{|c|c|c|c|c|c|c|c|c|}
\hline $\begin{array}{l}\text { Leaf } \\
\text { tissue }\end{array}$ & $\begin{array}{c}\text { Deoxyribose, } \\
\text { phosphodiester, } \\
\text { dA }\end{array}$ & $\begin{array}{c}\text { CO stretching } \\
(\mathrm{C}-\mathrm{O}-\mathrm{P}-\mathrm{O}-\mathrm{C}), \\
\mathrm{dG}\end{array}$ & $\begin{array}{l}\mathrm{P}-\mathrm{O} \text { sym. } \\
\text { stretching } \\
\text { of }\left(\mathrm{PO}_{2}{ }^{-}\right)\end{array}$ & $\mathrm{dA}$ & $\begin{array}{c}\mathrm{dC}, \mathrm{dG}, \\
\mathrm{dT}\end{array}$ & $\begin{array}{c}\text { Deoxyribose, } \\
\mathrm{dA}, \mathrm{dC}, \mathrm{dT}\end{array}$ & $\begin{array}{c}\mathrm{dG}(\mathrm{N} 7), \\
\mathrm{dA}\end{array}$ & $\begin{array}{c}\text { Tentative } \\
\text { assignment }\end{array}$ \\
\hline Potato & $\begin{array}{r}879 \\
15.4\end{array}$ & & & & & $\begin{array}{r}1455 \\
20\end{array}$ & & $\begin{array}{c}\nu, \mathrm{cm}^{-1} \\
\Delta \nu, \mathrm{cm}^{-1}\end{array}$ \\
\hline Sword fern & $\begin{array}{c}881 \\
13.2\end{array}$ & $\begin{array}{r}1047 \\
11.4\end{array}$ & $\begin{array}{r}1089 \\
15.4\end{array}$ & $\begin{array}{r}1124 \\
9.7\end{array}$ & & $\begin{array}{r}1453 \\
13.6\end{array}$ & & $\begin{array}{c}\nu, \mathrm{cm}^{-1} \\
\Delta \nu, \mathrm{cm}^{-1}\end{array}$ \\
\hline Scopolia & $\begin{array}{l}879 \\
15.4\end{array}$ & & & & & $\begin{array}{r}1455 \\
17.3\end{array}$ & & $\begin{array}{c}\nu, \mathrm{cm}^{-1} \\
\Delta \nu, \mathrm{cm}^{-1}\end{array}$ \\
\hline Redwood & $\begin{array}{r}879 \\
15.4\end{array}$ & $\begin{array}{r}1047 \\
13.5\end{array}$ & $\begin{array}{r}1087 \\
15.4\end{array}$ & & & $\begin{array}{r}1455 \\
21.5\end{array}$ & & $\begin{array}{c}\nu, \mathrm{cm}^{-1} \\
\Delta \nu, \mathrm{cm}^{-1}\end{array}$ \\
\hline Orchids & $\begin{array}{l}879 \\
14.4\end{array}$ & & $\begin{array}{l}1089 \\
13.2\end{array}$ & & & $\begin{array}{r}1452 \\
23\end{array}$ & & $\begin{array}{c}\nu, \mathrm{cm}^{-1} \\
\Delta \nu, \mathrm{cm}^{-1}\end{array}$ \\
\hline Chrysanthemum 1 & $\begin{array}{l}877 \\
17.9\end{array}$ & $\begin{array}{r}1043 \\
11.6\end{array}$ & & & $\begin{array}{c}1278(\mathrm{dC}) \\
14.4\end{array}$ & $\begin{array}{r}1453 \\
16.8\end{array}$ & & $\begin{array}{c}\nu, \mathrm{cm}^{-1} \\
\Delta \nu, \mathrm{cm}^{-1}\end{array}$ \\
\hline Chrysanthemum 2 & $\begin{array}{l}879 \\
15.1\end{array}$ & $\begin{array}{r}1047 \\
11.4\end{array}$ & $\begin{array}{r}1087 \\
15.4\end{array}$ & & $\begin{array}{c}1276(\mathrm{dC}) \\
10\end{array}$ & $\begin{array}{r}1452 \\
18\end{array}$ & & $\begin{array}{c}\nu, \mathrm{cm}^{-1} \\
\Delta \nu, \mathrm{cm}^{-1}\end{array}$ \\
\hline Common sundew & $\begin{array}{l}879 \\
14.92\end{array}$ & & $\begin{array}{r}1085 \\
19.4\end{array}$ & $\begin{array}{l}1122 \\
10.2\end{array}$ & $\begin{array}{r}1272 \\
7.8\end{array}$ & $\begin{array}{r}1452 \\
23.1\end{array}$ & $\begin{array}{r}1482 \\
10.6\end{array}$ & $\begin{array}{c}\nu, \mathrm{cm}^{-1} \\
\Delta \nu, \mathrm{cm}^{-1}\end{array}$ \\
\hline
\end{tabular}

Notes: dA - deoxyadenosine; $\mathrm{dG}$ - deoxyguanosine; $\mathrm{dC}$ - deoxycytidine; dT - thymidine.

themum 2 leaf tissues, respectively ( $0.69 \mathrm{ps})$. The fastest dynamics of this band was found for common sundew (global relaxation time $0.55 \mathrm{ps}$ ) and the slowest dynamics was detected in the case of orchids (global relaxation time $0.80 \mathrm{ps}$ ).

Similar slow molecular relaxation processes have been observed for the dA band at $1124 \mathrm{~cm}^{-1}$ in the case of sword fern (global relaxation time $1.09 \mathrm{ps}$ ) and common sundew (global relaxation time $1.04 \mathrm{ps}$ ), respectively. We have previously found, that the molecular relaxation processes are the slowest for the dA residues, as compared to those of all the other DNA molecular subgroups $[6,8]$.

In our study, the best vibrational energy transfer process was obtained for the $\mathrm{dC}$ band at $1278 \mathrm{~cm}^{-1}$ in the case of DNA extracted from chrysanthemum 1 (global relaxation time $0.74 \mathrm{ps}$ ). Besides, a slow dynamics has been found for the band near $1276 \mathrm{~cm}^{-1}$ in the case of DNA extracted from chrysanthemum 2 (global relaxation time $1.06 \mathrm{ps}$ ).

The global relaxation time characterizing the band at $1455 \mathrm{~cm}^{-1}$ varied between 0.46 and $0.78 \mathrm{ps}$. The maximum value, corresponding to the slowest relaxation processes belongs to the Raman band of sword fern DNA. The smallest global relaxation time and the largest half bandwidth, respectively, have been detected for FT-Raman band at $1455 \mathrm{~cm}^{-1}$, in the case of DNA extracted from orchids and common sundew, respectively.

For genomic DNA from potato, scopolia, redwood, orchids, chrysanthemum 2 and common sundew, the vibration near $1455 \mathrm{~cm}^{-1}$ has the fastest dynamics, as compared to the other structural groups, respectively.

Besides, we have observed, that the structural subgroups corresponding to the FT-Raman bands near $879,1047,1124$ and $1453 \mathrm{~cm}^{-1}$ of genomic DNA extracted from sword fern leaves, have the highest val- 
Table 2

Global relaxation times for molecular subgroups in genomic DNA from different leaf tissues

\begin{tabular}{|c|c|c|c|c|c|c|c|c|}
\hline $\begin{array}{l}\text { Leaf } \\
\text { tissue }\end{array}$ & $\begin{array}{c}\text { Deoxyribose, } \\
\text { phosphodiester, } \\
\text { dA }\end{array}$ & $\begin{array}{c}\text { CO stretching } \\
(\mathrm{C}-\mathrm{O}-\mathrm{P}-\mathrm{O}-\mathrm{C}), \\
\mathrm{dG}\end{array}$ & $\begin{array}{l}\mathrm{P}-\mathrm{O} \text { sym. } \\
\text { stretching } \\
\text { of }\left(\mathrm{PO}_{2}{ }^{-}\right)\end{array}$ & $\mathrm{dA}$ & $\begin{array}{c}\mathrm{dC}, \mathrm{dG}, \\
\mathrm{dT}\end{array}$ & $\begin{array}{c}\text { Deoxyribose, } \\
\mathrm{dA}, \mathrm{dC}, \mathrm{dT}\end{array}$ & $\begin{array}{c}\mathrm{dG}(\mathrm{N} 7), \\
\mathrm{dA}\end{array}$ & $\begin{array}{c}\text { Tentative } \\
\text { assignment }\end{array}$ \\
\hline Potato & $\begin{array}{r}879 \\
0.69\end{array}$ & & & & & $\begin{array}{r}1455 \\
0.53\end{array}$ & & $\begin{array}{c}\nu, \mathrm{cm}^{-1} \\
\tau, \mathrm{ps}\end{array}$ \\
\hline Sword fern & $\begin{array}{l}881 \\
0.80\end{array}$ & $\begin{array}{r}1047 \\
0.93\end{array}$ & $\begin{array}{r}1089 \\
0.69\end{array}$ & $\begin{array}{r}1124 \\
1.09\end{array}$ & & $\begin{array}{r}1453 \\
0.78\end{array}$ & & $\begin{array}{c}\nu, \mathrm{cm}^{-1} \\
\tau, \mathrm{ps}\end{array}$ \\
\hline Scopolia & $\begin{array}{l}879 \\
0.69\end{array}$ & & & & & $\begin{array}{r}1455 \\
0.61\end{array}$ & & $\begin{array}{c}\nu, \mathrm{cm}^{-1} \\
\tau, \mathrm{ps}\end{array}$ \\
\hline Redwood & $\begin{array}{l}879 \\
0.69\end{array}$ & $\begin{array}{r}1047 \\
0.79\end{array}$ & $\begin{array}{r}1087 \\
0.69\end{array}$ & & & $\begin{array}{r}1455 \\
0.49\end{array}$ & & $\begin{array}{c}\nu, \mathrm{cm}^{-1} \\
\tau, \mathrm{ps}\end{array}$ \\
\hline Orchids & $\begin{array}{l}879 \\
0.74\end{array}$ & & $\begin{array}{r}1089 \\
0.80\end{array}$ & & & $\begin{array}{r}1452 \\
0.46\end{array}$ & & $\begin{array}{c}\nu, \mathrm{cm}^{-1} \\
\tau, \mathrm{ps}\end{array}$ \\
\hline Chrysanthemum 1 & $\begin{array}{l}877 \\
0.59\end{array}$ & $\begin{array}{r}1043 \\
0.92\end{array}$ & & & $\begin{array}{c}1278(\mathrm{dC}) \\
0.74\end{array}$ & $\begin{array}{r}1453 \\
0.63\end{array}$ & & $\begin{array}{c}\nu, \mathrm{cm}^{-1} \\
\tau, \mathrm{ps}\end{array}$ \\
\hline Chrysanthemum 2 & $\begin{array}{l}879 \\
0.70\end{array}$ & $\begin{array}{r}1047 \\
0.93\end{array}$ & $\begin{array}{r}1087 \\
0.69\end{array}$ & & $\begin{array}{c}1276(\mathrm{dC}) \\
1.06\end{array}$ & $\begin{array}{r}1452 \\
0.59\end{array}$ & & $\begin{array}{c}\nu, \mathrm{cm}^{-1} \\
\tau, \mathrm{ps}\end{array}$ \\
\hline Common sundew & $\begin{array}{l}879 \\
0.71 \\
\end{array}$ & & $\begin{array}{r}1085 \\
0.55 \\
\end{array}$ & $\begin{array}{r}1122 \\
1.04 \\
\end{array}$ & $\begin{array}{r}1272 \\
1.36 \\
\end{array}$ & $\begin{array}{r}1452 \\
0.46 \\
\end{array}$ & $\begin{array}{r}1482 \\
1.00 \\
\end{array}$ & $\begin{array}{c}\nu, \mathrm{cm}^{-1} \\
\tau, \mathrm{ps} \\
\end{array}$ \\
\hline
\end{tabular}

Notes: $\mathrm{dA}$ - deoxyadenosine; $\mathrm{dG}$ - deoxyguanosine; $\mathrm{dC}$ - deoxycytidine; $\mathrm{dT}$ - thymidine.

ues of the global relaxation time, respectively, as compared to the same band parameter, corresponding to DNA extracted from other sources.

We have found that the bands at $879 \mathrm{~cm}^{-1}$ (deoxyribose, phosphodiester, dA) and $1455 \mathrm{~cm}^{-1}$ (deoxyribose, dA, dC, dT) are suitable for the study of dynamical behavior of molecular subgroups in genomic DNA extracted from leaf tissues.

Specific molecular relaxation processes, depending on the type of genomic DNA extracted from leaf tissues has been observed.

Besides, a comparison between different ranges of the Raman band parameters, upon changing the structure of nucleic acid, is given in Table 3.

\section{Conclusions}

Spontaneous Raman scattering can be used to study the fast (sub)picosecond dynamics of molecules $[8,12]$.

This paper presents a FT-Raman spectroscopic study into the vibrational total half bandwidths of molecular subgroups in eight genomic DNAs from leaf tissues [potato (Solanum tuberosum L.), sword fern (Nephrolepis exaltata L.), scopolia (Scopolia carniolica Jacq.), redwood (Sequoia sempervirens D. Don. Endl.), orchids (Cymbidium $\times$ hybrida), chrysanthemum (Dendranthema grandiflora Ramat.) and common sundew (Drosera rotundifolia L.)]. Besides, the corresponding global relaxation times have been derived. The Raman band parameters were obtained for the modes at $879 \mathrm{~cm}^{-1}$ (deoxyribose, phosphodiester, dA), $1047 \mathrm{~cm}^{-1}$ (CO stretching C-O-P-O-C, dG), $1089 \mathrm{~cm}^{-1}$ (P-O symmetric stretching of 
Table 3

Comparison between different ranges of the Raman band parameters, upon changing the structure of nucleic acid

\begin{tabular}{|c|c|c|}
\hline DNA molecules & $\begin{array}{l}\text { FWHM range, } \Delta \nu \\
\quad\left(\mathrm{cm}^{-1}\right)\end{array}$ & $\begin{array}{l}\text { Global relaxation time range, } \tau \\
(\mathrm{ps})\end{array}$ \\
\hline Genomic DNA from leaf tissues & $7.8-23.1$ & $0.46-1.36$ \\
\hline $\begin{array}{l}\text { Calf-thymus DNA at different } \mathrm{pH} \text { values, } \\
\text { in the presence of } \mathrm{Mg}^{2+} \text { ions }\end{array}$ & $10.2-31[5]$ & $0.34-1.04[5]$ \\
\hline $\begin{array}{l}\text { Calf-thymus DNA at different } \mathrm{pH} \text { values, } \\
\text { in the presence of } \mathrm{Mn}^{2+} \text { ions }\end{array}$ & $11-27[7]$ & $0.39-0.97[7]$ \\
\hline $\begin{array}{l}\text { Calf-thymus DNA at neutral and low } \mathrm{pH} \text {, } \\
\text { in the presence of } \mathrm{Mg}^{2+}, \mathrm{Ca}^{2+} \text { and } \mathrm{Na}^{+} \text {ions }\end{array}$ & $7.4-28.6[5]$ & $0.37-1.44[5]$ \\
\hline $\begin{array}{l}\text { Calf-thymus DNA at different } \mathrm{Mn}^{2+} \text { ions concentrations, } \\
\text { in the presence of } 10 \mathrm{mM} \mathrm{Na}^{+} \text {ions }\end{array}$ & $10-33.5[6]$ & $0.32-1.06[6]$ \\
\hline $\begin{array}{l}\text { Calf-thymus DNA at different } \mathrm{Mn}^{2+} \text { ions concentrations, } \\
\text { in the presence of } 150 \mathrm{mM} \mathrm{Na}^{+} \text {ions }\end{array}$ & $9-31.5[6]$ & $0.34-1.18[6]$ \\
\hline $\begin{array}{l}\text { Calf-thymus DNA at different } \mathrm{Zn}^{2+} \text { ions concentrations, } \\
\text { in the presence of } 10 \mathrm{mM} \mathrm{Na}^{+} \text {ions }\end{array}$ & $10-50[8]$ & $0.21-0.94[8]$ \\
\hline
\end{tabular}

$\mathrm{PO}_{2}{ }^{-}$) $1124 \mathrm{~cm}^{-1}(\mathrm{dA}), 1272 \mathrm{~cm}^{-1}(\mathrm{dC}, \mathrm{dG}, \mathrm{dT}), 1276 \mathrm{~cm}^{-1}(\mathrm{dC}), 1455 \mathrm{~cm}^{-1}$ (deoxyribose, $\mathrm{dA}, \mathrm{dC}$, $\mathrm{dT})$ and $1482 \mathrm{~cm}^{-1}(\mathrm{dG}, \mathrm{dA})$, characteristic to genomic DNAs from different leaf tissues [9]. It has been shown that changes in the (sub)picosecond dynamics of molecular subgroups in genomic DNAs from leaf tissues can be monitored with Raman spectroscopy.

The study of the vibrational total half bandwidths of genomic DNA from plant tissues, revealed a sensitivity of FWHM to the source of nucleic acid. Moreover, this proved to be dependent on the vibration under study. The Raman total half bandwidths of genomic DNA vibrations revealed a dynamic picture on a (sub)picosecond time scale. Full widths at half-maximum (FWHM) of the bands in genomic DNA from leaf tissues are typically in the wavenumber range from 7.8 to $23.1 \mathrm{~cm}^{-1}$. The total half bandwidths in the Raman spectra are sensitive to a dynamics active on a time scale from 0.46 to $1.36 \mathrm{ps}$.

The fastest and the slowest relaxation processes of different DNA structural subgroups, have been analyzed for several types of genomic DNA extracted from leaf tissues. Particularly, the slowest dynamics corresponding to the vibration near $1272 \mathrm{~cm}^{-1}$ takes place in the case of DNA extracted from common sundew.

A comparison between different time scales of the molecular dynamics, characterizing several DNA complexes, has been given. Some differences in the vibrational energy transfer processes of DNA subgroups have been observed upon changing the structure of DNA.

We have found that the bands at $879 \mathrm{~cm}^{-1}$ (deoxyribose, phosphodiester, dA) and $1455 \mathrm{~cm}^{-1}$ (deoxyribose, dA, dC, dT) are suitable for the study of dynamical behavior of molecular subgroups in genomic DNA extracted from leaf tissues.

\section{Acknowledgements}

The authors wish to thank to Prof. Onuc Cozar, "Babeş-Bolyai" University, Cluj-Napoca, Romania, for facilitating the FT-Raman spectroscopic measurements, to Dr. Adela Halmagyi, Institute of Biological Research, Cluj-Napoca, Romania for the preparation of genomic DNA from different plant tissues, and to Mr. Mircea D. Puia, "Babeş-Bolyai" University, Cluj-Napoca, Romania for FT-Raman spectroscopic 
measurements. Financial support from the Ministry of Education and Research of Romania, within the framework of IDEAS Program (Competition 2008, contract No. 519/2009), is gratefully acknowledged by us.

\section{References}

[1] A. Hernanz, I. Bratu and R. Navarro, J. Phys. Chem. B 108(7) (2004), 2438-2444.

[2] A. Hernanz, I. Bratu, R. Navarro, J.P. Huvenne and P. Legrand, J. Chem. Soc. Faraday Trans. 92(7) (1996), 1111-1115.

[3] T. Iliescu, S. Aştilean, I. Bratu, R. Grecu and D. Maniu, J. Chem. Soc. Faraday Trans. 92 (1996), 175-178.

[4] T. Iliescu, I. Bratu, R. Grecu, T. Veres and D. Maniu, J. Raman Spectrosc. 25 (1994), 403-407.

[5] C.M. Muntean and I. Bratu, Spectrosc. Int. J. 21(4) (2007), 193-204.

[6] C.M. Muntean and I. Bratu, Spectrosc. Int. J. 22(5) (2008), 345-359.

[7] C.M. Muntean and I. Bratu, Spectrosc. Int. J. 22(6) (2008), 475-489.

[8] C.M. Muntean, I. Bratu, K. Nalpantidis and M.A.P. Purcaru, Spectrosc. Int. J. 23(3,4) (2009), 141-154.

[9] C.M. Muntean, A. Halmagyi, M.D. Puia and I. Pavel, Spectrosc. Int. J. 23(2) (2009), 59-70.

[10] R. Navarro, I. Bratu and A. Hernanz, J. Phys. Chem. 97(36) (1993), 9081-9086.

[11] C. Otto, P.A. Terpstra and J. Greve, in: Fifth International Conference on the Spectroscopy of Biological Molecules, T. Theophanides et al., eds, Kluwer Academic, Dordrecht, 1993, pp. 55-58.

[12] C. Otto, P.A. Terpstra, G.M.J. Segers-Nolten and J. Greve, in: Spectroscopy of Biological Molecules, J.C. Merlin et al., eds, Kluwer Academic, Dordrecht, 1995, pp. 313-314.

[13] A.V. Rakov, Optika i Spektrosk. 7 (1959), 202-208.

[14] W. Saenger, in: Principles of Nucleic Acid Structure, C.R. Cantor, ed., Springer-Verlag, New York, 1984, p. 81.

[15] P.A. Terpstra, C. Otto and J. Greve, Biopolymers 41(7) (1997), 751-763.

[16] S. Woutersen, Y. Mu, G. Stock and P. Hamm, PNAS 98(20) (2001), 11254-11258. 


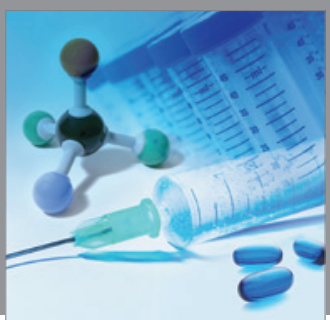

International Journal of

Medicinal Chemistry

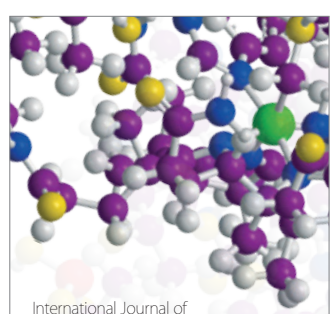

Carbohydrate Chemistry

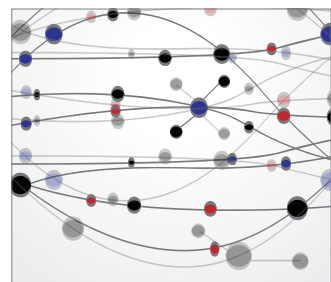

The Scientific World Journal
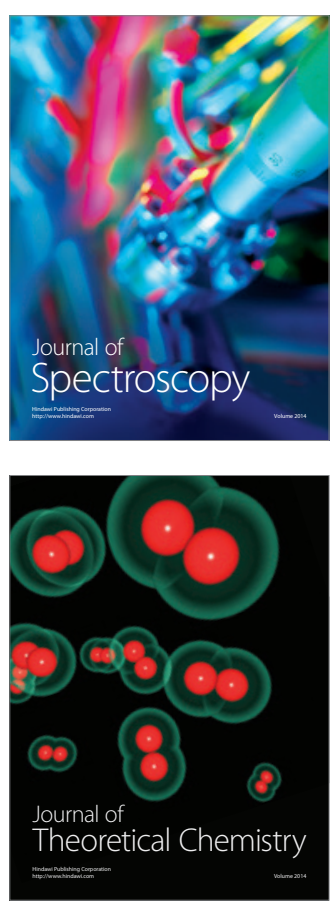
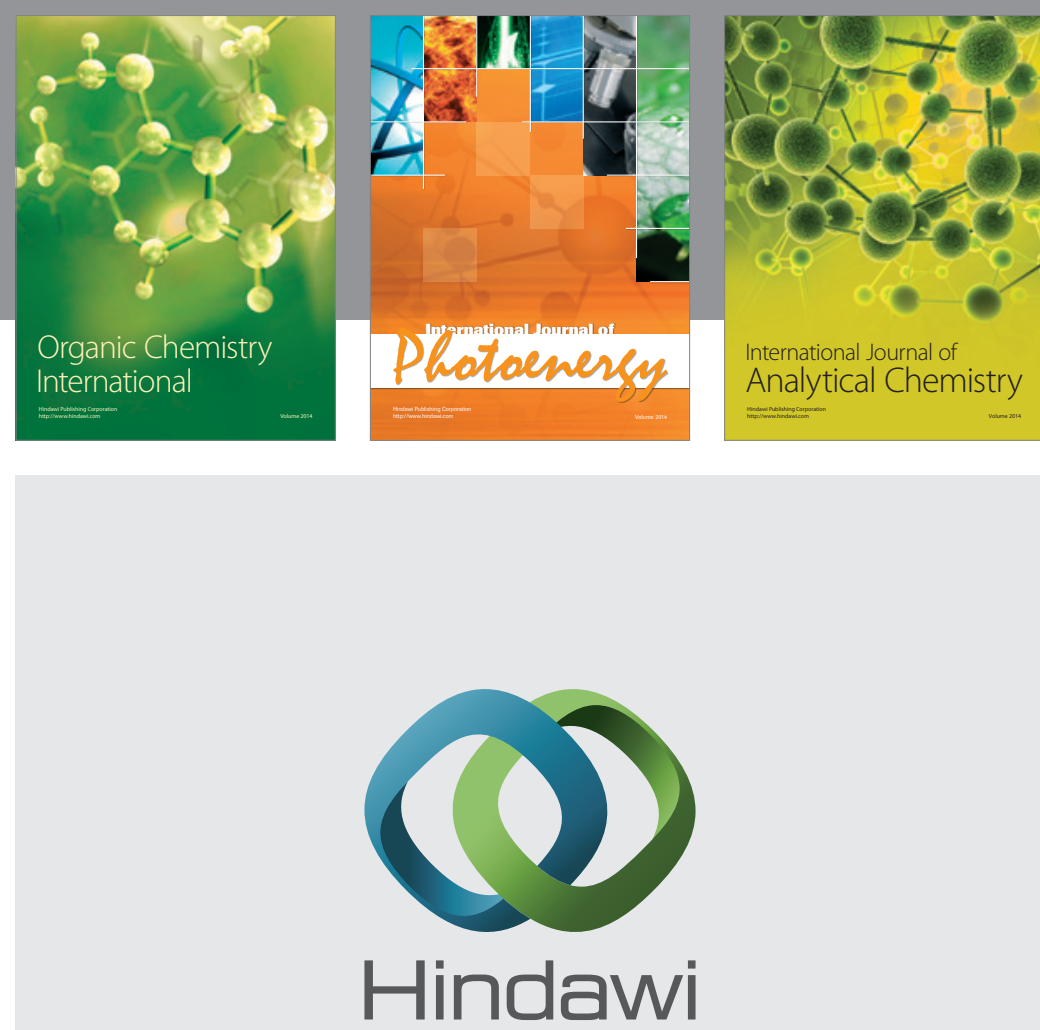

Submit your manuscripts at

http://www.hindawi.com
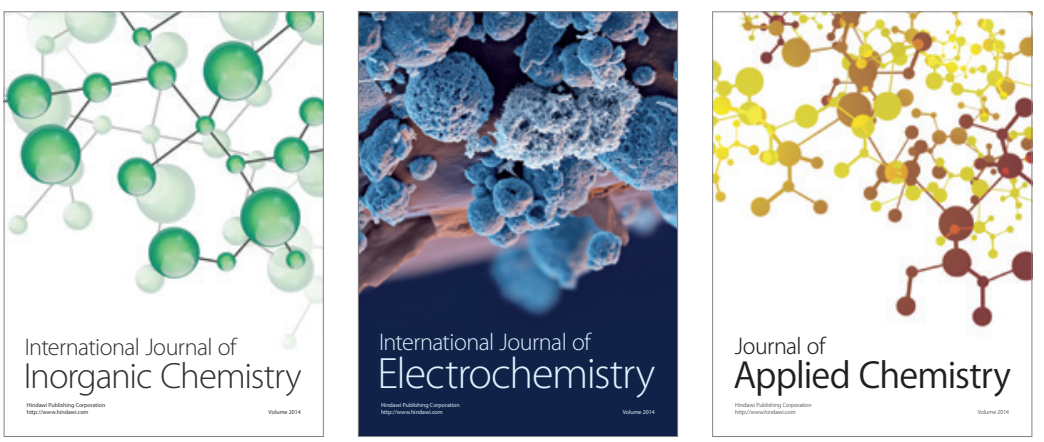

Journal of

Applied Chemistry
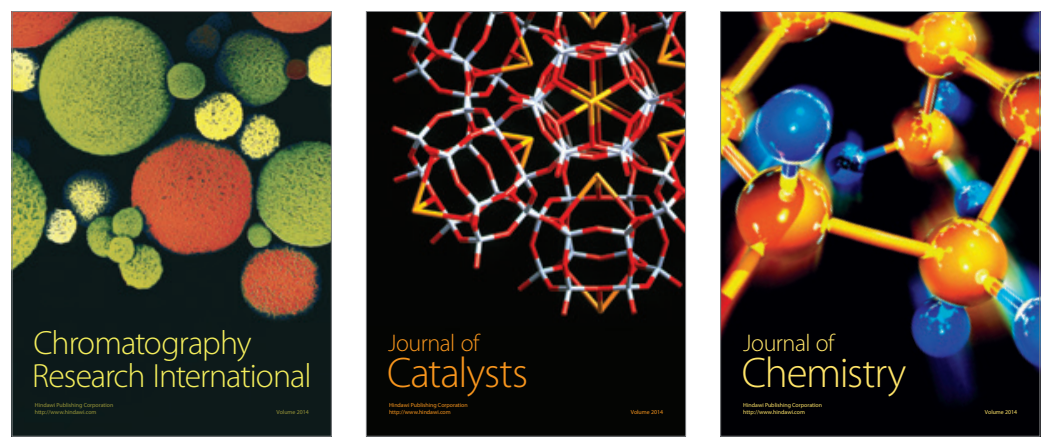
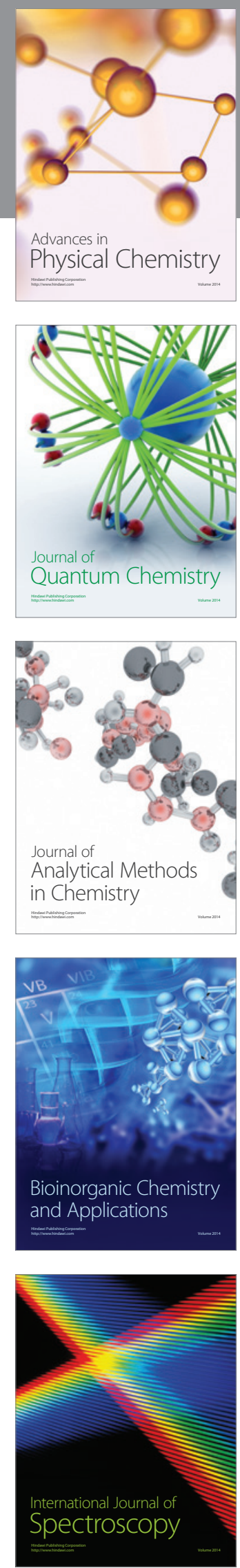